\title{
The Use of Topinambur (Jerusalem artichoke) Concentrate in the Curd Production
}

\author{
N.R. Chatinyan, K.Zh. Minasyan, A.E. Matevosyan, S.H. Gevorgyan \\ Armenian National Agrarian University \\ narachat@mail.ru, karen.minasyan@anau.am, andranik.matevosyan.1994@mail.ru, sargis.gevorgyan17@yahoo.com
}

\section{A R T I CLE I N FO}

\section{Keywords:}

\section{topinambur}

(Jerusalem artichoke),

curd,

concentrate,

hydrolysis,

inulin

\begin{abstract}
A B S T RA C T
Curd production technology upon the use of topinambur (Jerusalem artichoke) tuber has been developed. For the curd production, hydrolyzed concentrate obtained from the tuber of Jerusalem artichoke has been used in the form of herbal supplement. New food product exceeds the traditional one in its biological values due to enrichment with carbohydrates, vitamins, nonessential and essential amino acids. The optimal dose of introducing the hydrolyzed concentrate has been also determined.
\end{abstract}

The use of hydrolyzed concentrate of Jerusalem artichoke solution reduces the coagulation duration of milk mixture and increases the product yield; at the same time it saturates the product with inulin.

\section{Introduction}

Each civilized country seeks to ensure welfare of its population by making the food production sector viable and prosperous branch of economy with clear understanding that food product is the foremost need for humanity. The nation's health and mental capacity also depends on the quantity and quality of the food product consumed by the population. One of the most important prerequisites of a healthy nation is the use of high-quality and vitamin rich food, which very often stays behind the scope of the society being engaged in multiple social problems. For most people the food safety and wholesomeness is not so much important as its price availability. Taking into account the aforementioned issues the use of protein food becomes rather relevant.
Curds, curd mass, curd cheese and albumin curd belong to the range of high-protein dairy products. Curd is a rather useful milk concentrate with high content of calcium salts. Curd products are easily and almost completely digested by the human body. They are rich in essential amino acids (methionine), vitamins (particularly $A, E$, $P, B_{2}, B_{6}$ and $\left.B_{12}\right)$, folic acid, calcium salt, iron, sodium, magnesium, copper, zinc, fluorine and phosphorus. Just due to the mentioned compounds curd is digested rather easily. As a food product variety curd is necessary for the growth and regeneration of all body tissues. It is useful for nervous system, heart activity and blood system. It should be added that the high content of calcium makes curd product indispensable in case of tuberculoses, bone 
fractures, diseases of hematopoietic system and rickets.

The main objective of the current work is to produce a curd product rich in vitamins, amino acids, protein and micro-macro-nutrients. To this end the following activities should be accomplished:

- to study the effect of topinambur on the biotechnological procedures,

- to study the role and impact of herbal supplement on the produced foodstuff,

- to test the optimal dose ratio of the topinambur concentrate used for the curd production

- to study the biochemical, physicochemical and microbiological processes taking place throughout the curd production process.

The use of specially processed topinambur in curd production process has been investigated for the first time. Due to this crop the product acquires easily digestible carbohydrates, vitamins $\left(B_{1}, B_{3}, B_{5}, B_{6}\right)$, folic acid, calcium and minerals $(\mathrm{K}, \mathrm{Ca}, \mathrm{Mg}, \mathrm{Na}, \mathrm{Fe})$. Topinambur contains inulin, which has an absolute sorbent capacity; it binds and expels a huge amount of toxins penetrated into the body intestine via food intake or during digestion. Besides, inulin stimulates the motility of gastrointestinal tract. Addition of topinambur concentrate affects the water absorption capacity and the protein content in the curd products.

\section{Materials and methods}

Curd belongs to the range of high-protein dairy products and is produced via milk coagulation with pure lactic acid cultures. Topinambur is endowed with soothing, immune-boosting, body-strengthening, anti-sclerotic, toxin-removing, cell-membrane protecting (in case of excessive glucose, water amount grows up and damages the cells) effects. According to some data, topinambur (mannose) can prevent the occurrence and development of autoimmune diseases and cancers. The energy value of $100 \mathrm{~g}$ topinambur tuber amounts to $73 \mathrm{kcal}$. The same mass contains $78 \mathrm{~g}$ water, $2.54 \mathrm{~g}$ ash, $2 \mathrm{~g}$ protein, slight amount of fats $-0.01 \mathrm{~g}$ unsaturated fatty acids, $0.067 \mathrm{~g}$ omega-3, $0.256 \mathrm{~g}$ omega- 6 and saturated fatty acids $0.145 \mathrm{~g}$ (https:// www.dasaran.am).

Inulin is a compound sugar consisting of residual fructose molecules. It is not dissolved in cold water, while due to the inulosucrase enzyme it gets dissolved in the lukewarm acidic gastric juice, then swells up and expands into the colon without splitting. Thereafter it covers the intestinal mucosa, due to which the transfer of glucose and cholesterol into the blood is retarded. Up to $14 \mathrm{~g}$ and more inulin can be found in $100 \mathrm{~g}$ topinambur tuber. Plant sterols $(9 \mathrm{mg}$, $16.4 \%$ ) also have anti-cholesterol effect. Inulin absorbs harmful and toxic matters, including glucose and fructose. In recent years it has been disclosed that inulin really reduces the burden of insulin producing organ, but it can't substitute insulin. It is important to know that topinambur contains chrome (3.5-18 mkg, $24 \%)$ which increases tissue susceptibility towards the insulin, and vanadium $(24 \%)$ imitating the insulin effect. The general chemical composition of topinambur tubers (Table 1,2) depends on the crop variety and harvest time.

Table 1. The general chemical composition of topinambur tubers*

\begin{tabular}{|l|c|}
\hline \multicolumn{1}{|c|}{$\begin{array}{c}\text { Chemical } \\
\text { composition }\end{array}$} & $\begin{array}{c}\text { Quantity } \\
\text { \% }\end{array}$ \\
\hline Dry matters & $20.2-25$ \\
\hline Inulin & $2.5-20$ \\
\hline Membrane & $0.6-1.25$ \\
\hline Nitrogen containing matters & $1.4-2$ \\
\hline Proteins & up to 2 \\
\hline Ash & $0.9-1.2$ \\
\hline
\end{tabular}

Table 2. Amino-acid composition of topinambur tubers*

\begin{tabular}{|l|l|l|}
\hline $\begin{array}{c}\text { Amino } \\
\text { acids }\end{array}$ & Tubers & $\begin{array}{c}\text { Green } \\
\text { mass }\end{array}$ \\
\hline Protein & 8.33 & 0.50 \\
\hline Lysin & 0.33 & 0.46 \\
\hline Histidine & 0.21 & 1.10 \\
\hline Arginine & 0.45 & 1.02 \\
\hline Threonine & 0.29 & 0.53 \\
\hline Tyrosine & 0.12 & 0.13 \\
\hline Valine & 1.33 & 1.06 \\
\hline Phenylalanine & 0.48 & 0.38 \\
\hline Leucine & 0.89 & 2.11 \\
\hline Tryptophan & 0,83 & 2,12 \\
\hline
\end{tabular}

*Composed by the authors. 


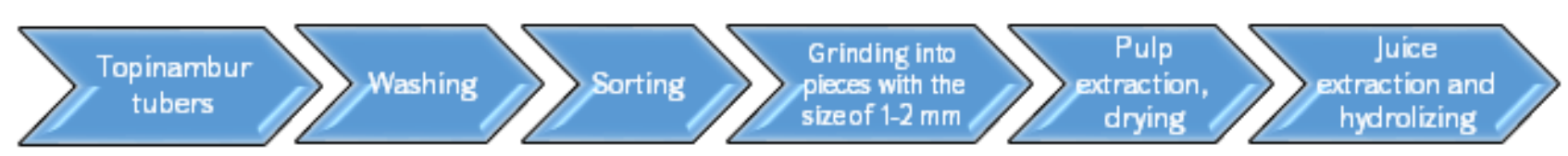

Figure 1. Technology of water-soluble extract production (composed by the authors).

Based on the use of the crop varieties and their samples a highly profitable, loss-free, resource-saving agri-food production technology encompassing all production phases for complex processing of topinambur tubers, has been developed (Polyanskiy, et al., 1999).

The technology of producing water-soluble extract out of the inulin-containing topinambur tubers is introduced in Figure 1.

\section{Results and discussions}

The experimental samples of the curd mass have been produced in the laboratory of the chair of "AnimalBased Foodstuff Processing Technology", ANAU. The experimental and control samples of the curd mass have been produced from the same batch of normalized milk through common technology. After determining the physicochemical indices of the used raw material (milk), the pasteurized milk is cooled to the coagulation temperature $-30-32{ }^{\circ} \mathrm{C}$. Then $40 \% \mathrm{CaCl}_{2}$ solution $(40 \mathrm{~g})$ per $100 \mathrm{~kg}$ milk and 2-3\% coagulant (ferment) is added to the heated milk (Dilanyan, 1962).

All ingredients have been added by stirring up the milk uninterruptedly. $1.5 \%-2.0 \%$ topinambur concentrate and $3 \%-5 \%$ hydrolyzed topinambur juice is mixed in the experimented sample. The end of milk coagulation and the final coagulum is determined through its $\mathrm{pH}$ value, which should be equal to 5.1-5.2 (or according to the serum titratable acidity $75-85^{\circ} \mathrm{T}$ ) and by the serum form isolated from the coagulum. If during the coagulum cutting, equal cutting edges are formed with glossy smooth surfaces, it means that the coagulum is ready for further processing. The serum emerged in the cutting place should be transparent and of light greenish color (Beglaryan, R., Beglaryan, A., 2003, Zobkova, 2019).

The quantities of topinambur concentrate and hydrolyzed juice are introduced in Table 3, based on which the optimal dose with the account of organoleptic indicators (Table 5) has been identified.
Table 3. The optimal quantity of topinambur concentrate and hydrolyzed juice*

\begin{tabular}{|l|c|c|c|}
\hline Sample & $\begin{array}{c}\text { The quantity } \\
\text { of topinambur } \\
\text { concentrate, } \\
\%\end{array}$ & $\begin{array}{c}\text { The quantity } \\
\text { of hydro- } \\
\text { lyzed juice, } \\
\%\end{array}$ & $\begin{array}{c}\text { Duration of } \\
\text { coagulation, }\end{array}$ \\
\hline & 0 & 0 & $h$ \\
\hline Control & 0 & 7.0 & 8 \\
\hline Experimental 1 & 2.0 & 5.0 & 6.5 \\
\hline Experimental 2 & 1.5 & 3 & 6 \\
\hline Experimental 3 & 1.0 & & 7 \\
\hline
\end{tabular}

*Composed by the authors.

Table 4. The technological indicators of the curd produced through the developed technology (Gharagulayan, 1980)

\begin{tabular}{|c|c|c|}
\hline Technological indicators & Experimental & Control \\
\hline $\begin{array}{l}\text { Fat content of the concentrate, } \\
\%\end{array}$ & 3.9 & 3.9 \\
\hline Titratable acidity, ${ }^{\circ} \mathrm{T}$ & 19 & 19 \\
\hline Pasteurization temperature, ${ }^{\circ} \mathrm{C}$ & 74 & 74 \\
\hline Holding minutes & $2-3$ & $2-3$ \\
\hline Coagulation temperature, ${ }^{\circ} \mathrm{C}$ & $30-32$ & $30-32$ \\
\hline The dose of added coagulant, $\%$ & 3 & 3 \\
\hline $\begin{array}{l}\text { The dose of added calcium } \\
\text { chloride, } g\end{array}$ & $\begin{array}{l}40 \mathrm{~g} \text { per } \\
1 \text { ton of milk }\end{array}$ & $\begin{array}{c}40 \mathrm{~g} \text { per } \\
1 \text { ton of milk }\end{array}$ \\
\hline $\begin{array}{l}\text { The dose of topinambur } \\
\text { concentrate, \% }\end{array}$ & 1.5 & 0 \\
\hline $\begin{array}{l}\text { The dose of hydrolyzed } \\
\text { topinambur juice, } \%\end{array}$ & 5 & 0 \\
\hline Coagulation duration, hour & 6 & 8 \\
\hline $\begin{array}{l}\text { Acidity at the end of } \\
\text { coagulation, }{ }^{0} T\end{array}$ & 80 & 88 \\
\hline Coagulum $P H$ & 5.1 & 5.2 \\
\hline $\begin{array}{l}\text { Coagulum cutting and } \\
\text { granulation, minute }\end{array}$ & 25 & 30 \\
\hline Granule size, $m m$ & $18-20$ & $18-20$ \\
\hline Fat content of whey, $\%$ & 0.2 & 0.3 \\
\hline
\end{tabular}




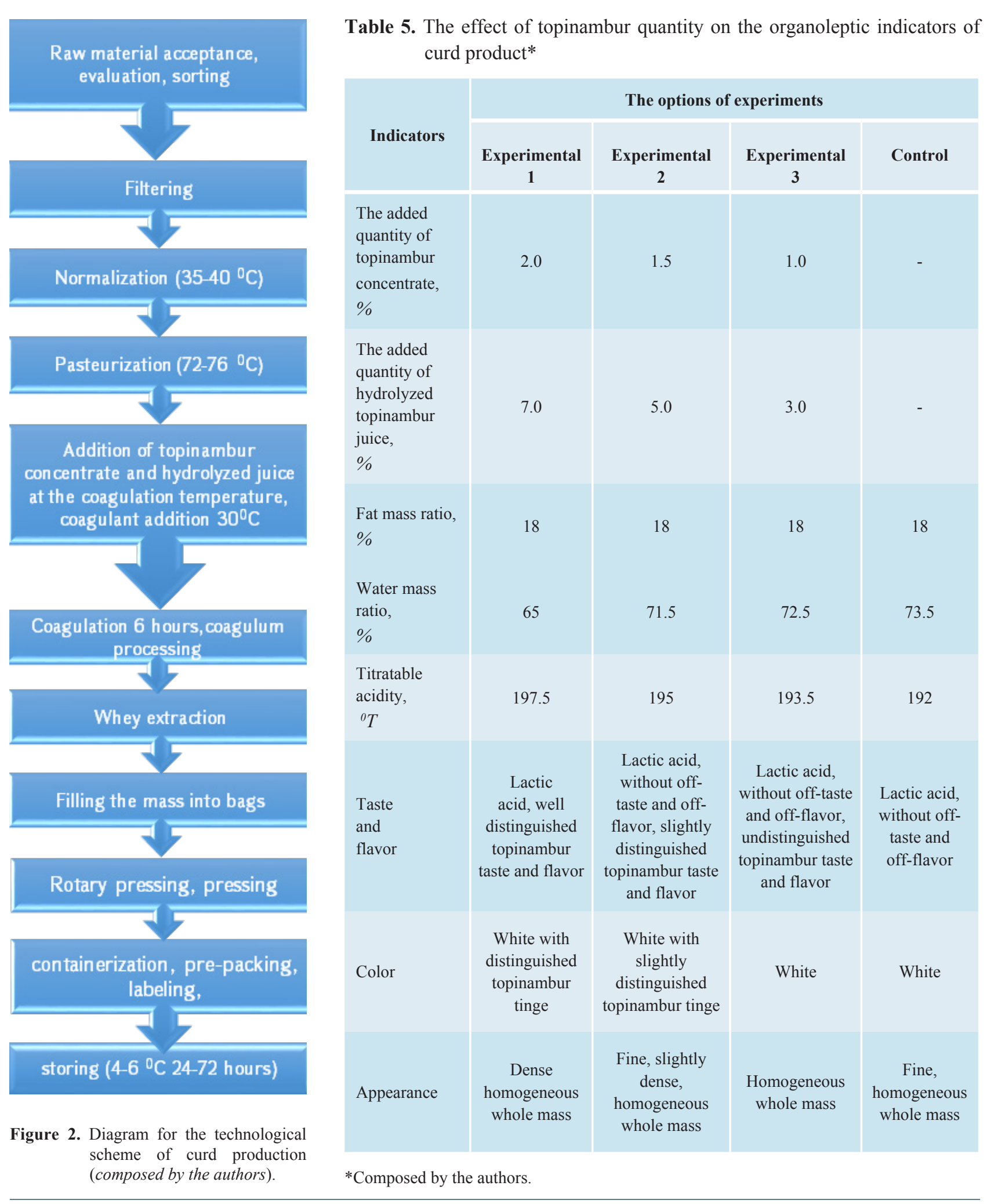

The new technological scheme of curd production is introduced in Figure 2, while the technological indicators of the produced curd are presented in Table 4.
Due to the topinambur concentrate the curd product content is supplemented with easily digested carbohydrates, vitamins and minerals. The mentioned products can serve as a 
prophylactic and treating measures for the patients suffering from the diseases of gastrointestinal tract and diabetes. The extract which is subjected to hydrolysis is also very useful for diabetics.

Considering the aforementioned we can state that the use of plant concentrates enables to diversify food product varieties, improve the food quality and use it in the therapeutic and prophylactic diet.

The processing of topinambur tubers was conducted in the following way: after processing of $1 \mathrm{~kg}$ topinambur tuber its net mass made $988 \mathrm{~g}$. After grinding the tubers, its pulp weight made $850 \mathrm{~g}$ and the extract $-570 \mathrm{~g}$. The pulp was dried up at the temperature of $50{ }^{\circ} \mathrm{C}$ and $305 \mathrm{~g}$ concentrate was resulted. The amount of dry matters dissolved in the extract of topinambur tubers was examined by means of KERN ORA 32BA refractometer, according to which they made $22 \%$. Then $570 \mathrm{~g}$ extract was filtered with filter paper and it became $550 \mathrm{~g}$. The filtered solution was hydrolyzed with $2 \mathrm{~g}$ citric acid salt (boiling for 20 minutes) resulting in $382 \mathrm{~g}$ hydrolyzed solution. The hydrolyzed solution was diluted with distilled water 3 times, as a result of which the amount of dry matters made $63 \%$. Relatively higher organoleptic indices were recorded in the curd mass with $1.5 \%$ concentrate and $5 \%$ hydrolyzed solution. The study results have indicated that the application of optimal dose of topinambur tubers increases the curd mass yield by $1.1 \%$. As a result, the curd mass obtains specific taste, flavor and homogeneous fine density.

The application of plant additives doesn't affect the microbiological indicators and promotes the production of food variety with new delicate flavor properties, high nutritional and biological value and with relatively longer shelf life.

\section{Conclusion}

Based on the results of scientific-research and theoreticalexperimental investigations the following conclusions have been inferred:

The feasibility of using topinambur tubers in the curd production has been theoretically justified and empirically confirmed. It has been proved that the biological value of the curd product manufactured with the experimented topinambur tubers is more complete, than that of observed in traditional food product. This is related to the availability of topinambur tubers rich in carbohydrates, essential amino acids and vitamins, which make the food product easily digestible. It is recommended to use topinambur tubers' concentrate (upon drying method) and hydrolyzed juice, which contains a great amount of carbohydrates, (mainly inulin) as herbal supplements in dairy industry. In the initial stage it is transformed into fructose, glucose and other carbohydrate containing mediums via acidic hydrolization.

Thus it is also recommended to use the optimal dose of topinambur tubers' concentrate and hydrolyzed solution, which results in the reduction of curd mass coagulation period and in the increase of the product yield.

\section{References}

1. Beglaryan, R.A., Beglaryan, A.R. (2003), Milk and Dairy Product Technology. Teaching Manual. Yerevan, - 177 p.

2. Dilanyan, Z.Q. (1962). Milk and Dairy Product Technology. Armstate Agricultural-Publishing house. Yerevan, - $471 \mathrm{p}$.

3. Gharagulyan, M. (1980). // Technological and Bacteriological Inspection in Milk Processing Enterprises, - p. 235.

4. Polyanskiy, K.K., Rodinova, N.S., Glagoleva, L.E. (1999). Topinambur: Prospects of its Use in the Dairy Industry, - Voronezh: Publishing House of the Voronezh State University, - 104 p.

5. Zobkova, Z.S. (2019). Development of the Curd Base Content for Functional Pasty Product // Dairy Industry, - № 3, - pp. 15-17.

6. https://www.dasaran.am/apps/wiki/view/id/8385 (accessed on 23.04.20). 